\title{
Pengaruh Jenis Pupuk Cair dan Diameter Pot pada Budidaya Selada (Lactuca Sativa,L) Secara Hidroponik
}

Ursulina Uto Keraf ${ }^{\mathrm{a}}$, dan Krisantus Tri Pambudi Raharjo ${ }^{\mathrm{b}}$

${ }^{a}$ Fakultas Pertanian, Universitas Timor, Kefamenanu, TTU - NTT, Indonesia, email: ursulinautikeraf@gmail.com

${ }^{b}$ Fakultas Pertanian, Universitas Timor, Kefamenanu, TTU - NTT, Indonesia, email: initriraharjaa@gmail.com

\section{Article Info}

Article history:

Received 13 Desember 2018

Received in revised form 25 Mei 2019

Accepted 3 Juli 2019

DOI:

https://doi.org/10.32938/sc.v4i02.593

\section{Keywords:}

Diameter pot

Jenis pupuk cair

Lactuca sativa, L

\section{Abstrak}

Selada (Lactuca sativa $\mathrm{L}$ ) merupakan jenis tanaman hortikultura berumur pendek yang dapat ditanam baik di dataran rendah maupun dataran tinggi. Tujuan penelitian, untuk mengetahui pengaruh jenis pupuk cair dan diameter pot terhadap pertumbuhan dan hasil tanaman Selada pada budidaya secara hidroponik serta untuk memperoleh jenis pupuk cair dan diameter pot yang optimal guna meningkatkan pertumbuhan dan hasil tanaman selada pada budidaya secara hidroponik. Media tanam yang digunakan untuk hidroponik harus memenuhi persyaratan yaitu harus ringan, porous dan bersih. Budidaya secara hidroponik sistem subtrat untuk tanaman sayuran sebaiknya menggunakan media yang ringan, salah satunya adalah arang sekam. Penelitian ini dilaksanakan dikebun Fakultas Pertanian Universitas Timor, Kabupaten TTU menggunakan Rancangan Acak Lengkap (RAL) faktorial 3x3 diulang 3 kali. Faktor pertama adalah jenis pupuk cair organik, yaitu: AB Mix $\left(\mathrm{J}_{1}\right)$, Teh guano $\left(\mathrm{J}_{2}\right)$, dan Teh kompos daun Gamal (Gliricidia sepium) $\left(\mathrm{J}_{3}\right)$. Faktor kedua adalah diameter pot yaitu: $8,5 \mathrm{~cm}\left(\mathrm{D}_{1}\right), 18 \mathrm{~cm}\left(\mathrm{D}_{2}\right)$ dan $23 \mathrm{~cm}\left(\mathrm{D}_{3}\right)$. Hasil penelitian menunjukkan interaksi antara perlakuan diameter pot dan jenis pupuk cair tidak terjadi pada semua parameter pengamatan, tetapi penggunaan diameter pot $18 \mathrm{~cm}$ dengan jenis teh kompos daun gamal meningkatkan hasil lebih tinggi pada pengamatan bobot segar total tanaman, bobot segar berangkasan, dan bobot segar hasil tanaman Selada.

\section{Pendahuluan}

Selada (Lactuca sativa $L$ ), merupakan sayuran yang berumur pendek dan dapat ditanam di dataran rendah maupun dataran tinggi (Edi dan Yusri, 2010) Kandungan Selada dalam 1.000 gram terdiri dari Protein 1,2 g, Lemak 0,2 g, Karbohidrat 2,9 g, Ca 22,0 g, P 25,0 g, Fe 0,5 g, Vitamin A $162 \mathrm{mg}$, Vitamin B $0,04 \mathrm{~g}$, dan Vitamin C $8,0 \mathrm{~g}$. Sistem hidroponik dapat memberikan suatu lingkungan pertumbuhan yang lebih terkontrol. Dengan pengembangan teknologi kombinasi sistem hidroponik dengan membran mampu mendayagunakan air, nutrisi, pestisida secara nyata lebih efisien (minimalis system) dibandingkan dengan kultur tanah (terutama untuk tanaman berumur pendek). Sekam padi digunakan sebagai pakan ternak atau dibuang begitu saja tanpa ada pemanfaatan adanya tanam-menanam selain itu sekam padi juga memiliki porositas yang baik dan bersifat menahan air sehingga larutan yang diberikan dapat bertahan lama. Arang sekam mengandung N 0,32\%, P 0,15\%, $\mathrm{K} 0,31 \%$, Ca 0,95\%, dan Fe 180 ppm, Mn 80 ppm, Zn 14,1 ppm dan PH 6,8. Karakteristik lain dari arang sekam adalah ringan (berat jenis $0,2 \mathrm{~kg} / \mathrm{l}$ ) Pemilihan penggunaan arang sekam sebagai media hidroponik didasarkan pada arang sekam ringan dan lebih steril dari hama dan penyakit, Sirkulasi udara tinggi, kapasitas menahan air tinggi, berwarna kehitaman, sehingga dapa mengabsorbsi sinar matahari dengan efektif (Wuryaningsih, 1996). Arang sekam mempunyai sifat yang mudah mengikat air, tidak mudah menggumpal, harganya relatif murah. Agar arang tidak berserakan dibutuhkan wadah penampungan yang dibuat dengan pot. Pot berhubungan langsung dengan jumlah media tanam yang digunakan untuk budidaya tanaman. Wadah adalah tempat tumbuh penyedia nutrisi tanaman yang juga berperan untuk melindungi perakaran dari kekeringan atau kerusakan serta membentuk system perakaran yang menguntungkan (Tinus \& Mc Donald, 1979).

Media tanam dengan ukurun wadah yang besar saja tidak cukup untuk mendukung kehidupan tanaman. Oleh karena itu perlu suplai nutrisi kepada tanaman baik melalui akar maupun melalui daun. Suplai nutrisi dapat berupa pupuk anorganik maupun pupuk pupuk organik. Pupuk organik dapat berbentuk padat maupun cair. Pupuk cair didapatkan dari hasil fermentasi sisa-sisa tanaman yang dicampurkan dengan bahan lain dan air atau dapat juga berupa teh dari hasil pengomposan. Teh kompos adalah seduhan ekstrak kompos menggunakan air sebagai bahan pengekstrak (Ingham, 2005 dalam Berek, 2017). Penelitian ini bertujuan untuk mengetahui pengaruh jenis pupuk cair dan diameter pot terhadap pertumbuhan dan hasil tanaman selada pada budidaya secara hidroponik, serta untuk memperoleh jenis pupuk cair dan diameter po yang optimal meningkatkan pertumbuhan dan hasil tanaman selada pada budidaya secara hidroponik

\section{Metode}

Penelitian ini dilaksanakan dikebun Fakultas Pertanian Universitas Timor, Kelurahan Sasi, Kecamatan Kota Kefamenanu, Kabupaten TTU.pada bulan Mei - Juli 2018. Penelitian ini menggunakan Rancangan Acak Lengkap (RAL) faktorial $3 \times 3$ diulang 3 kali. Faktor pertama adalah jenis pupuk cai organik, yaitu: $\mathrm{AB}$ Mix $\left(\mathrm{J}_{1}\right)$,teh guano $\left(\mathrm{J}_{2}\right)$, dan teh kompos daun gamal $\left(\mathrm{J}_{3}\right)$. Faktor kedua adalah diameter pot yaitu: $8,5 \mathrm{~cm}\left(\mathrm{D}_{1}\right), 18 \mathrm{~cm} \quad\left(\mathrm{D}_{2}\right)$ dan $23 \mathrm{~cm}$ $\left(D_{3}\right)$. Kombinasi perlakuannya adalah $\mathrm{J}_{1} \mathrm{D}_{1}, \mathrm{~J}_{2} \mathrm{D}_{1}, \mathrm{~J}_{3} \mathrm{D}_{1}, \mathrm{~J}_{1} \mathrm{D}_{2}, \mathrm{~J}_{2} \mathrm{D}_{2}, \mathrm{~J}_{3} \mathrm{D}_{3}, \mathrm{~J}_{1} \mathrm{D}_{3}$, $\mathrm{J}_{2} \mathrm{D}_{3}$, dan $\mathrm{J}_{3} \mathrm{D}_{3}$. Fariabel pengamatan pada penelitian meliputi; suhu Biochar, $\mathrm{pH}$ Biochar, Penambahan Air, Jumlah daun, Luas Daun, Bobot segar tota tanaman, Berat segar hasil per tanaman trubus, Berat segar brangkasan. Data hasil pengamatan dianalisis dengan menggunakan Sidik Ragam (Anova) Rancangan Acak Lengkap (RAL). Rata-Rata perlakuan selanjutnya diuji lanjut dengan menggunakan Tukey test dengan tingkat signifikasi 5\% sesuai petunjuk Gomes dan Gomes (2010) Analisis data menggunakan program SAS 9.1.

\section{Hasil dan Pembahasan 3.1 Hasil} Suhu Biochar $\left({ }^{\circ} \mathrm{C}\right)$

Hasil sidik ragam (Anova) menunjukkan bahwa tidak terjadi interaksi antar diameter pot dan jenis pupuk cair tidak terjadi pada pengamatan suhu biochar tetapi pemberian teh kompos daun gamal menghasilkan suhu media tanaman (biochar) lebih rendah dan berbeda nyata dengan perlakuan lainnya (Tabel 1). Sedangkan diameter pot $23 \mathrm{~cm}$ menghasilkan suhu paling terendah $(27,92)$

$\underline{\text { Tabel 1. Suhu biochar }}$

\begin{tabular}{ccccc}
\hline \multirow{2}{*}{$\begin{array}{c}\text { Diameter Pot } \\
(\mathrm{cm})\end{array}$} & \multicolumn{3}{c}{ Jenis Pupuk Cair } & \multirow{2}{*}{ Rerata } \\
\cline { 2 - 4 } & Teh Guano & AB Mix & Teh Kompos & \\
\hline 8.5 & 28.1 & 28.57 & 27.27 & $27.98 \mathrm{a}$ \\
18 & 27.6 & 28.9 & 27.3 & $27.93 \mathrm{a}$ \\
23 & 28.2 & 28.27 & 27.3 & $27.92 \mathrm{a}$ \\
\hline Rerata & $27.97 \mathrm{ab}$ & $28.58 \mathrm{a}$ & $27.29 \mathrm{~b}$ & $(-)$ \\
\hline
\end{tabular}

Keterangan: Angka pada baris dan kolom diikuti huruf yang sama menunjukan beda pada tingkat nyata (0) 5\% menurut uji DMRT. (-) tidak terjadi interaksi antar faktor.

\section{pH Biochar}

Hasil sidik ragam (anova) menunjukkan bahwa tidak terjadi interaksi antara pemberian jenis pupuk cair dan diameter pot terhadap pengamatan $\mathrm{pH}$ biochar. Aras perlakuan jenis pupuk cair maupun diameter pot tidak beda nyata terhadap $\mathrm{pH}$ biochar (Tabel.2)

\begin{tabular}{ccccc} 
Tabel 2. pH Biochar & \multicolumn{3}{c}{} & \multirow{2}{*}{ Rerata } \\
\cline { 1 - 4 } Diameter Pot & \multicolumn{3}{c}{ Jenis Pupuk Cair } & \\
\cline { 2 - 4 }$(\mathrm{cm})$ & $6.98 \mathrm{a}$ \\
\hline 8.5 & 6.1 & 5.98 & 5.86 & $6.18 \mathrm{a}$ \\
18 & 6.2 & 5.94 & 6.39 & $6.20 \mathrm{a}$ \\
23 & 6.14 & 6.35 & 6.1 & $(-)$ \\
\hline Rerata & $6.15 \mathrm{a}$ & $6.09 \mathrm{a}$ & $6.12 \mathrm{a}$ & Teh Kompos \\
\hline Keterangan: Angka pada baris dan kolom diikuti huruf yang sama menunjukan beda
\end{tabular}

Keterangan: Angka pada baris dan kolom diikuti huruf yang sama menunjukan
pada tingkat nyata (匹) $5 \%$ menurut uji DMRT (-) tidak terjadi interaksi antar faktor

\section{Penambahan Air (L)}

Hasil sidik ragam (Anova) menunjukkan bahwa tidak terjadi interaksi anatara diameter pot dan jenis pupuk cair. Perlakuan jenis pupuk cair menunjukkan bahwa penambahan air saat tanaman berumur 32 HST memperlihatkan perlakuan jenis teh kompos daun gamal paling sedikit dan berbeda tidak nyata dengan perlakuan lainnya. Sedangkan pada perlakuan diameter pot $23 \mathrm{~cm}$ menghasilkan penambahan air lebih sedikit dan tidak berbeda nyata dengan diameter pot lainnya (Tabel.3)

\section{Jumlah Daun (Helai)}

Hasil sidik ragam (Anova) menunjukkan tidak terjadi interaksi antara pemberian jenis pupuk cair dan diameter pot terhadap pengamatan jumlah daun tanaman selada darat. Selanjutnya hasil uji lanjut menunjukan tidak adanya pengaruh nyata pada perlakuan diameter pot. Pada pengamatan 35 HST diameter pot dengan ukuran $23 \mathrm{~cm}$ menghasilkan jumlah daun paling banyak tetapi tidak berbeda nyata dengan diameter pot lainnya. Ini berarti semakin besar diameter pot maka tanaman berkembang lebih baik. Hal ini sejalan dengan Penelitian Purbiati dkk, (1998) dimana wadah dengan diameter $16 \mathrm{~cm}$ dengan campuran media pasir + pupuk kandang + sekam $(1: 1: 1)$ menghasilkan jumlah daun terbanyak dibandingkan perlakuan lainnya (diameter $8 \mathrm{~cm}$ dan 12 $\mathrm{cm}$ ). Sedangkan pada perlakuan jenis pupuk cair jumlah daun terbanyak dihasilkan oleh perlakuan teh kompos daun gamal pada saat tanaman berumur 35 HST yang berbeda nyata dengan perlakuan lain. Hal ini berarti teh kompos 
yang berasal dari hijauan gamal lebih baik dari the guano dan AB-mix (Tabel. 4). Berek, dkk (2017) bahwa tanaman selada yang diberi perlakuan teh kompos kirinyuh menghasilkan jumlah daun lebih banyak dari pada teh guano pada semua dosis (150 dan 250 per tanaman).

Tabel 3. Penambahan Air (L)

\begin{tabular}{|c|c|c|c|c|c|}
\hline \multirow{2}{*}{$\begin{array}{c}\text { Waktu } \\
\text { Pengamatan } \\
\text { (HST) }\end{array}$} & \multirow{2}{*}{$\begin{array}{l}\text { Diameter } \\
\text { Pot }(\mathrm{cm})\end{array}$} & \multicolumn{3}{|c|}{ Jenis Pupuk Cair } & \multirow[b]{2}{*}{ Rerata } \\
\hline & & Teh Guano & AB Mix & Teh Kompos & \\
\hline \multirow{4}{*}{18} & 8.5 & 326.67 & 506.67 & 483.33 & $438.89 \mathrm{a}$ \\
\hline & 18 & 266.67 & 316.67 & 316.67 & $300.00 \mathrm{a}$ \\
\hline & 23 & 456.67 & 480 & 283.33 & $406.67 \mathrm{a}$ \\
\hline & Rerata & $350.00 \mathrm{a}$ & $434.44 \mathrm{a}$ & $361.11 \mathrm{a}$ & $(-)$ \\
\hline \multirow{4}{*}{24} & 8.5 & 306.67 & 336.67 & 350 & $331.11 \mathrm{a}$ \\
\hline & 18 & 265 & 286.67 & 273.33 & $275.00 \mathrm{a}$ \\
\hline & 23 & 366.67 & 333.33 & 323.33 & $341.11 \mathrm{a}$ \\
\hline & Rerata & $312.78 \mathrm{a}$ & $318.89 \mathrm{a}$ & $315.56 \mathrm{a}$ & $(-)$ \\
\hline \multirow{4}{*}{26} & 8.5 & 396.67 & 351.67 & 316.67 & $355.00 \mathrm{a}$ \\
\hline & 18 & 290 & 240 & 230 & $253.33 \mathrm{a}$ \\
\hline & 23 & 360 & 383.33 & 381.67 & $375.00 \mathrm{a}$ \\
\hline & Rerata & $348.89 \mathrm{a}$ & $325.00 \mathrm{a}$ & $309.44 \mathrm{a}$ & $(-)$ \\
\hline \multirow{4}{*}{32} & 8.5 & 210 & 330 & 293.33 & $277.78 \mathrm{a}$ \\
\hline & 18 & 370 & 223.33 & 170 & $254.44 \mathrm{a}$ \\
\hline & 23 & 213.33 & 275 & 243.33 & $243.89 \mathrm{a}$ \\
\hline & Rerata & $264.44 \mathrm{a}$ & $276.11 \mathrm{a}$ & $235.56 \mathrm{a}$ & $(-)$ \\
\hline
\end{tabular}

Keterangan: Angka pada baris dan kolom diikuti huruf yang sama menunjukan beda pada tingkat nyata (a) 5\% menurut uji DMRT (-) tidak terjadi interaksi antar faktor.

Tabel 4. Jumlah Daun (Helai)

\begin{tabular}{|c|c|c|c|c|c|}
\hline \multirow{2}{*}{$\begin{array}{c}\text { Waktu } \\
\text { Pengamatan } \\
\text { (HST) }\end{array}$} & \multirow{2}{*}{$\begin{array}{l}\text { Diameter Pot } \\
(\mathrm{cm})\end{array}$} & \multicolumn{3}{|c|}{ Jenis Pupuk Cair } & \multirow[b]{2}{*}{ Rerata } \\
\hline & & Teh Guano & AB Mix & Teh Kompos & \\
\hline \multirow{4}{*}{14} & 8.5 & 4.33 & 4 & 4 & $4.11 \mathrm{a}$ \\
\hline & 18 & 4 & 4 & 4.33 & $4.11 \mathrm{a}$ \\
\hline & 23 & 3.67 & 4 & 4 & $3.89 \mathrm{a}$ \\
\hline & Rerata & $4.00 \mathrm{a}$ & $4.00 \mathrm{a}$ & $4.11 \mathrm{a}$ & $(-)$ \\
\hline \multirow{4}{*}{21} & 8.5 & 4.67 & 5.33 & 5 & $5.00 \mathrm{a}$ \\
\hline & 18 & 4.33 & 5.33 & 5 & $4.89 \mathrm{a}$ \\
\hline & 23 & 4 & 5 & 5 & $4.67 \mathrm{a}$ \\
\hline & Rerata & $4.33 \mathrm{~b}$ & $5.22 \mathrm{a}$ & $5.00 \mathrm{ab}$ & $(-)$ \\
\hline \multirow{4}{*}{28} & 8.5 & 5.67 & 5.67 & 5.67 & $5.67 \mathrm{a}$ \\
\hline & 18 & 5 & 6.67 & 6.67 & $6.11 \mathrm{a}$ \\
\hline & 23 & 5.33 & 6.67 & 5.67 & $5.89 \mathrm{a}$ \\
\hline & Rerata & $5.33 \mathrm{~b}$ & $6.33 \mathrm{a}$ & $6.00 \mathrm{ab}$ & $(-)$ \\
\hline \multirow{4}{*}{35} & 8.5 & 6.33 & 6.33 & 7 & $6.56 \mathrm{a}$ \\
\hline & 18 & 5.67 & 6.67 & 7.33 & $6.56 \mathrm{a}$ \\
\hline & 23 & 6.33 & 6.33 & 8 & $6.89 \mathrm{a}$ \\
\hline & Rerata & $6.11 \mathrm{~b}$ & $6.44 \mathrm{ab}$ & $7.44 \mathrm{a}$ & $(-)$ \\
\hline
\end{tabular}

Keterangan: Angka pada baris dan kolom diikuti huruf yang sama menunjukan beda pada tingkat nyata( () $5 \%$ menurut uji DMRT. (-) tidak terjadi interaksi antar faktor

\section{Luas Daun (cm)}

Hasil sidik ragam (Anova) menunjukkan bahwa tidak terjadi interaksi antar pemberian jenis pupuk terhadap pengamatan luas daun selada darat. Selanjutnya hasil uji lanjut menunjukkan bahwa diameter pot dengan ukuran $23 \mathrm{~cm}$ menghasilkan luas daun paling besar tetapi tidak berbeda nyata dengan diameter pot lainnya. Hal ini sejalan dengan hasil penelitian Bui dkk., (2015) bahwa polybag dengan ukuran paling besar $(20 \times 25 \mathrm{~cm})$ menghasilkan luas daun paling besar dibandingkan dengan ukuran polybag lainnya $(15 \times 20 \mathrm{~cm}$ dan $20 \times 20 \mathrm{~cm}$ ) ini berarti ukuran pot sangat berpengaruh terhadap pertumbuhan dan perkembangan tanaman. Sedangkan jenis pupuk cair AB-mix menghasilkan luas daun terluas yang berbeda nyata dengan perlakuan lainnya. Hal ini berarti jenis pupuk cair AB-mix banyak mengandung unsur hara yang berperan untuk proses perpanjangan dan pelebaran sel-sel daun. Maitimu dan Suryanto, (2018) bahwa AB-mix banyak mengandung unsur nitrogen yang berperan dalam pembentukan dan perluasan daun. Nitrogen merupakan salah satu unsur yang berperan dalam pertumbuhan vegetative tanaman terutama dating dan daun (Tabel. 5)

Tabel 5. Luas Daun (cm)

\begin{tabular}{ccccc}
\hline \multirow{2}{*}{$\begin{array}{c}\text { Diameter Pot } \\
(\mathrm{cm})\end{array}$} & \multicolumn{4}{c}{ Jenis Pupuk Cair } \\
\cline { 2 - 5 } & Teh Guano & AB Mix & Teh Kompos & Rerata \\
\hline 8.5 & 46,65 & 121,38 & 40,43 & $69,49 \mathrm{a}$ \\
18 & 54,23 & 91,60 & 43,17 & $63,00 \mathrm{a}$ \\
23 & 44,50 & 144,65 & 28,65 & $72,60 \mathrm{a}$ \\
\hline Rerata & $48,46 \mathrm{~b}$ & $119,21 \mathrm{a}$ & $37,42 \mathrm{~b}$ & $(-)$ \\
\hline
\end{tabular}

Keterangan: Angka pada baris dan kolom diikuti huruf yang sama menunjukan beda pada tingkat nyata( ( ) 5\% menurut uji DMRT. (-) tidak terjadi interaksi antar faktor

\section{Bobot Segar Total Tanaman (g)}

Hasil sidik ragam (Anova) menunjukkan tidak terjadi interaksi antar diameter pot dan jenis pupuk cair pada pengamatan bobot segar total tanaman (Tabel. 6). Hasil uji lanjut menunjukkan bahwa baik diameter pot maupun jenis pupuk cair tidak berbeda nyata. Diameter pot $18 \mathrm{~cm}$ menghasilkan berat segar total tanaman paling tinggi tetapi tidak berbeda nyata dengan diameter pot lainnya. Sedangkan pada perlakuan jenis pupuk cair menunjukkan bahwa perlakuan teh kompos daun gamal menghasilkan berat segar total tanaman paling tinggi tetapi tidak berbeda nyata dengan perlakuan lainnya.

\begin{tabular}{ccccc}
\multicolumn{2}{l}{ Tabel 6. Bobot Segar total $(\mathrm{g})$} & \multicolumn{2}{l}{ Terata } \\
\cline { 2 - 4 } $\begin{array}{c}\text { Diameter Pot } \\
(\mathrm{cm})\end{array}$ & \multicolumn{3}{c}{ Jenis Pupuk Cair } & \\
\hline 8.5 & 56.66 & 61.36 & 53.56 & $57.19 \mathrm{a}$ \\
18 & 40.38 & 55.86 & 91.54 & $62.59 \mathrm{a}$ \\
23 & 33.38 & 58.61 & 62.14 & $51.38 \mathrm{a}$ \\
\hline Rerata & $43.47 \mathrm{a}$ & $58.61 \mathrm{a}$ & $69.08 \mathrm{a}$ & $(-)$ \\
\hline
\end{tabular}

Keterangan: Angka pada baris dan kolom diikuti huruf yang sama menunjukan beda pada tingkat nyata (@) 5\% menurut uji DMRT. (-) tidak terjadi interaksi antar faktor.

\section{Bobot Segar Brangkasan (g)}

Hasil sidik ragam (Anova) menunjukkan bahwa tidak terjadi interaksi antara pemberian jenis pupuk terhadap pengamatan bobot segar berangkasan. Hasil uji lanjut menunjukkan bahwa perlakuan diameter pot maupun jenis pupuk cair tidak berbeda nyata. Berat segar brangkasan paling rendah dihasilkan oleh diameter pot $23 \mathrm{~cm}$ sedangkan perlakuan jenis pupuk cair paling rendah dihasilkan oleh AB-mix (Tabel 7).

Tabel 7. Bobot Segar Brangkasan (g)

\begin{tabular}{ccccc}
\hline \multirow{2}{*}{$\begin{array}{c}\text { Diameter Pot } \\
(\mathrm{cm})\end{array}$} & \multicolumn{3}{c}{ Jenis Pupuk Cair } & \multirow{2}{*}{ Rerata } \\
\cline { 2 - 4 } & Teh Guano & AB Mix & Teh Kompos & \\
\hline 8,5 & 18.68 & 11.22 & 11.78 & $13.90 \mathrm{a}$ \\
18 & 8.04 & 11.33 & 25.9 & $15.09 \mathrm{a}$ \\
23 & 7.93 & 7.76 & 17.71 & $11.13 \mathrm{a}$ \\
\hline Rerata & $11.55 \mathrm{a}$ & $10.10 \mathrm{a}$ & $18.46 \mathrm{a}$ & $(-)$ \\
\hline Keterangan: Angka pada baris dan kolom diikuti huruf yang sama menunjukan beda pada
\end{tabular}
tingkat nyata(a) $5 \%$ menurut uji DMRT. (-) tidak terjadi interaksi antar faktor

\section{Bobot Segar Hasil per Tanaman (g)}

Hasil sidik ragam (Anova) menunjukkan tidak terjadi pengaruh interaksi antara jenis pupuk cair $\mathrm{AB}$ mix dan teh guano pada bobot segar hasil per tanaman. Hasil uji lanjut menujukkan bahwa baik perlakuan diameter pot maupun perlakuan jenis pupuk cair tidak berbeda nyata. Berat segar hasil per tanaman paling tinggi dihasilkan oleh diameter pot $18 \mathrm{~cm}$ sedangkan pada perlakuan jenis pupuk cair dihasilkan oleh the kompos daun gamal (Tabel.8).

Tabel 8. Bobot Segar Hasil per Tanaman (g)

\begin{tabular}{ccccc}
\hline Diameter Pot & \multicolumn{3}{c}{ Jenis Pupuk Cair } & \multirow{2}{*}{ Rerata } \\
\cline { 2 - 4 }$(\mathrm{cm})$ & Teh Guano & AB Mix & Teh Kompos & \\
\hline 8,5 & 34.9 & 49.83 & 38.15 & $40.96 \mathrm{a}$ \\
18 & 26 & 44.22 & 67.71 & $45.98 \mathrm{a}$ \\
23 & 25.15 & 50.75 & 45.33 & $40.41 \mathrm{a}$ \\
\hline Rerata & $28.69 \mathrm{a}$ & $48.27 \mathrm{a}$ & $50.40 \mathrm{a}$ & $(-)$ \\
\hline Keterangan & angka &
\end{tabular}

Keterangan: Angka pada baris dan kolom diikuti huruf yang sama menunjukan beda pada tingkat nyata(a) 5\% menurut uji DMRT. (-) tidak terjadi interaksi antar faktor.

\subsection{Pembahasan}

Hasil pengamatan parameter suhu terendah 27,3 pada pot berdiameter 18 dengan pupuk teh kompos daun gamal. Hasil dari seluruh pengamatan menunjukkan faktor tunggal jenis pupuk organik tidak berpengaruh nyata, tetapi secara umum menunjukkan teh kompos daun gamal memberikan pertumbuhan paling baik, diikuti pupuk organik jenis $\mathrm{AB}$ mix selanjutnya teh kompos guano. Setiap spesies tanaman memiliki batas pertumbuhan maksimal, walaupun tidak berpengaruh nyata diduga penggunaan ember berdiameter 18 $\mathrm{cm}$ sudah cukup memberikan ruang (medium) tumbuh yang optimal sehingga meningkatkan hasil tanaman selada paling tinggi dalam penelitian ini. Penggunaan pot yang berdiameter $23 \mathrm{~cm}$ diduga lebih meningkatkan penguapan air melalui medium (evaporasi), sedangkan penggunaan pot dengan diameter $8,5 \mathrm{~cm}$ kurang memberikan medium bagi akar sehingga menghambat pertumbuhan, oleh karenanya hasil tanaman lebih tinggi pada tanaman yang ditumbuhkan dalam pot berdiameter $18 \mathrm{~cm}$. Tanaman yang diberi perlakuan jenis teh kompos guano, memiliki pertumbuhan daun yang paling luas, tetapi kebutuhan air yang lebih tinggi dibanding tanaman yang terdapat pada po berdiameter $18 \mathrm{~cm}$ dengan pupuk teh kompos daun gamal justru memiliki tingkat penambahan air yang lebih sedikit hingga akhir pengamatan. Diduga bahwa daun yang lebih luas meningkatkan laju transpirasi tanaman sehingga kebutuhan airnya besar. Pada parameter hasil selada darat yang ditanaman dalam ember berdiameter 18 dan diberi pupuk teh kompos daun gamal pertumbuhannya lebih baik dibandingkan perlakuan lainnya. 


\section{Simpulan}

Hasil penelitian menunjukkan bahwa perlakuan diameter pot maupun perlakuan jenis pupuk cair tidak terjadi interaksi. Perlakuan pot $18 \mathrm{~cm}$ mampu menekan penambahan air irigasi, jumlah daun yang banyak, bobot segar total tanaman, dan bobot segar hasil per tanaman terbaik. Perlakuan jenis pupuk cair kompos daun gamal mampu menekan penambahan jumlah air, jumlah daun terbanyak, bobot segar total tanaman, dan bobot segar hasil per tanaman.

\section{Pustaka}

Berek Arnoldus Klau, Syprianus Ceunfin, Roberto I.C.O Taolin, Eduardus Yosef Neonbeni, Maksimus Johanes Seran., 2017., Efek Biochar Dan Teh Kompos Terhadap Pertumbuhan Dan Hasil Selada Darat (Lactuca Sativa L) Di Tanah Vertisol Semiarid., J.Floratek 12 (2): 101-114

Berek Arnoldus Klau., 2017., Teh Kompos dan Pemanfaatannya sebagai Sumber Hara dan Agen Ketahanan Tanaman., Savana Cendana 2(4) $68-70$

Bui Florentina, Maria Afnita Lelang, \& Roberto I. C. O. Taolin., 2015. Pengaruh Komposisi Media Tanam dan Ukuran Polybag Terhadap Pertumbuhan dan Hasil Tomat (Licopercicum escelentum, Mill). Savana Cendana 1 (1) 1-7

Edi, S dan A. Yusri. 2010. Budidaya Sawi Hijau. Jurnal Agribisnis. Balai Pengkajian Teknologi Pertanian. Jambi.

Gomez, K. A. Dan A.A Gomes. 1995. Prosedur Statitik untuk Penelitian Pertanian Edisi ke 2 Jakarta (Indonesia): UI Press.

Ingham, E. R. 2005. The Compost Tea Brewing Manual. Soil Foodweb Inc. Oregon, USA.

Maitimu Diah Kartika \& Agus Suryanto., 2018., Pengaruh Media Tanam Dan Konsentrasi AB-Mix Pada Tanaman Kubis Bunga System Hidroponik Substrat., Jurnal Produksi Tanaman., Vol 6 No 4.

Purbiati, T., Dasi, D.W. dan R.S. Sentot. 1998. Optimasi Wadah dan Media Tumbuh Pembibitan Untuk Efisiensi Pengangkutan Bibit Mangga. Jurnal Hortikultura, Vol 8 No 1. BPPP Pusat Penelitian dan Pengembangan Hortikultura, Jakarta, Indonesia. 957-968

Tinus, R.W. and S.E. Mc. Donald. 1979. How to Grow Tree Seedling in Container in Green House, General Technical Report. RM 60 US Department of Agriculture. 256 hal.

Wuryaningsih, S.1996. Pertumbuhan Beberapa Setek Melati pada Tiga Macam Media Agrin. J.Penelitian Pertanian. 5(3):50-57. 